\title{
Pristine Soils Mineralize 3-Chlorobenzoate and 2,4-Dichlorophenoxyacetate via Different Microbial Populations
}

\author{
ROBERTA R. FULTHORPE,* ALBERT N. RHODES, $\dagger$ AND JAMES M. TIEDJE \\ Center for Microbial Ecology and Department of Crop and Soil Sciences, \\ Michigan State University, East Lansing, Michigan 48824-1101
}

Received 8 August 1995/Accepted 19 January 1996

\begin{abstract}
Biodegradation of two chlorinated aromatic compounds was found to be a common capability of the microorganisms found in the soils of undisturbed, pristine ecosystems. We used 2,4-dichlorophenoxyacetate (2,4-D) and 3-chlorobenzoate (3CBA) as enrichment substrates to compare populations of degrading bacteria from six different regions making up two ecosystems. We collected soil samples from four Mediterranean (California, central Chile, the Cape region of South Africa, and southwestern Australia) and two boreal (northern Saskatchewan and northwestern Russia) ecosystems that had no direct exposure to pesticides or to human disturbance. Between 96 and 120 samples from each of the six regions were incubated with $50 \mathrm{ppm}$ of $\left[\mathrm{U}-{ }^{14} \mathrm{C}\right] 2,4-D$ or $\left[\mathrm{U}_{-}{ }^{14} \mathrm{C}\right] 3 \mathrm{CBA}$. Soils from all regions samples mineralized both $2,4-\mathrm{D}$ and $3 \mathrm{CBA}$, but 3CBA was mineralized without a lag period, while $2,4-D$ was generally not mineralized until the second week. 3CBA degradative capabilities were more evenly distributed spatially than those for 2,4-D. The degradative capabilities of the soils were readily transferred to fresh liquid medium. 3CBA degraders were easily isolated from most soils. We recovered 610 strains that could release carbon dioxide from ring-labeled 3CBA. Of these, 144 strains released chloride and degraded over $80 \%$ of $1 \mathrm{mM} 3 \mathrm{CBA}$ in 3 weeks or less. In contrast, only five 2,4-D degraders could be isolated, although a variety of methods were used in an attempt to culture the degraders. The differences in the distribution and culturability of the bacteria responsible for 3CBA and 2,4-D degradation in these ecosystems suggest that the two substrates are degraded by different populations. We also describe a ${ }^{14} \mathrm{C}$-based microtiter plate method that allows efficient screening of a large number of samples for biodegradation activity.
\end{abstract}

The contamination of ecosystems with halogenated organic compounds from industrial and agricultural sources has fueled research into these frequently toxic or bioaccumulatable compounds. 3-Chlorobenzoate (3CBA), a product of bacterial transformations of polychlorinated biphenyls, and 2,4-dichlorophenoxyacetate $(2,4-\mathrm{D})$, a commonly used herbicide, have been used as models for the study of the evolution of chloroaromatic degradative pathways. The evolution of chloroaromatic degradation pathways has been assumed to be recent, driven by the selective pressure exerted by the presence of anthropogenic chloroorganics in the environment. Accordingly, researchers wishing to isolate $3 \mathrm{CBA}$ or $2,4-\mathrm{D}$ degraders have sampled agricultural or industrially contaminated sites and have met with success $(2,4,7,15,17,19,21,23,26,30,34$, $40,42,43)$. Other studies support the complementary hypothesis that environments that have not been exposed to chloroorganics do not harbor chloroaromatic degraders $(3,9,10,12$, $13,20,22,25,36)$. In particular, Brunsbach and Reineke showed that soils require inoculation with a chlorobenzoate degrader before degradation will take place (3). Hickey et al. (22) considered the degradation of chlorobenzoates to be the limiting factor in the disappearance of polychlorinated biphenyls. Hernandez et al. (20) sought culturable chlorobenzoate utilizers in three Panamanian soils and found none above the detection limit $\left(10^{3} / \mathrm{g}\right)$ of the plating method they used. Even polychlorinated biphenyl-contaminated sediments accumulate

\footnotetext{
* Corresponding author. Present address: Scarborough Campus, University of Toronto, Scarborough, Ontario, Canada M1C 1A4.

$\dagger$ Present address: Armstrong Laboratory, Tyndall Air Force Base, FL 32403-5317.
}

chlorobenzoates for up to several weeks prior to their disappearance (18).

Genetic studies on the majority of known 2,4-D and 3CBA degraders support the notion that recently evolved genes are used by bacteria to mineralize these compounds. 3CBA and 2,4-D are converted to chlorocatechols, which are mineralized via a modified ortho cleavage pathway encoded by highly homologous operons, suggestive of a monophyletic origin of the genes $(16,39)$. Often the genes are carried on conjugative plasmids and have been isolated from very different parts of the world, presumably having spread globally via interspecies transfer events $(2,7,26)$. However, recent work has begun to uncover a higher diversity of genes: a protocatechuate pathway has been found for 3CBA degradation (28), and a very high degree of genetic diversity has been documented in the 2,4-D degraders $(10,24,38)$. These new findings suggest that selection for these genotypes may have been operating before the anthropogenic production of chlorinated organic compounds.

The objective of this study was to determine if chloroaromatic degradation takes place in soils of uncontaminated, pristine ecosystems and, if possible, to isolate bacteria that can grow on these substrates. A longer-term goal, not addressed in this paper, is the elucidation of the role that biogeography may play in determining the pattern of genotypes present. Accordingly, we sampled soils from six different geographic regions representative of two biome types. These regions had no previous direct exposure to anthropogenically produced halogenated compounds.

This paper describes the ability of microbial populations in undisturbed and uncontaminated soils to mineralize 3CBA and 2,4-D. We show that this ability is widespread and that $3 \mathrm{CBA}$ 
degraders are easily obtained from these sources but that 2,4-D degraders are distinctly different from $3 \mathrm{CBA}$ degraders in their culturability. In addition, we present a new method for rapidly quantifying the rate of degradation of chemicals in a large number of samples.

\section{MATERIALS AND METHODS}

Site choice. Since our long-range goal is to compare the bacterial flora from similar and dissimilar ecosystems from around the world, we chose regions with similar climates and as far as possible the same soil orders. We focused on two biomes in six geographic regions. Within each region we sampled several sites. The Mediterranean sclerophyllous woodland regions included California, southwestern Australia, the Cape region of South Africa (five sites sampled in each), and central Chile (four sites sampled). The two boreal forest regions were in northern Saskatchewan (five sites) and northwestern Russia (four sites). Sites were chosen in nature preserves, remote areas, or wilderness parks when possible. When these criteria could not be met, sites were chosen from areas with no documented exposure to chloroaromatic pesticides and no history of cultivation, excavation, or construction activity. The precise locations and other site characteristics are given in Table 1.

Soil sampling and characterization. Thirty individual soil samples were collected at 5-m intervals along a $200-\mathrm{m}$ transect at each site. For each sample, the organic litter was removed to expose mineral soil; a 30-cm-deep, $2.5-\mathrm{cm}$-diameter core was taken, and the top $5 \mathrm{~cm}$ of the sample was discarded. The soil cores were placed in sterile plastic bags, shipped on ice, and stored at $4^{\circ} \mathrm{C}$ before use. They were stored for a maximum of 2 months prior to enrichment. Intersample contamination was avoided by cleaning the corers with ethanol and flame sterilization between each sampling.

Soil moisture content was determined by drying soil overnight at $100^{\circ} \mathrm{C}$. Five samples chosen from evenly spaced intervals in each transect were used for soil $\mathrm{pH}$ determination, and a similarly chosen five samples were pooled and blended for particle size and carbon and nitrogen analyses. For $\mathrm{pH}$ determinations, a slurry was made by vortexing $1 \mathrm{~g}$ of soil in $5 \mathrm{ml}$ of distilled water for $1 \mathrm{~min}$. Particle size analyses to obtain sand, silt, and clay contents of soils were performed by a modified hydrometer method in which the clay content was determined after $8 \mathrm{~h}$ (5). Carbon and nitrogen contents of the soils were determined on oven-dried, ground samples in a Carlo Erba NA 1500 Series 2 Nitrogen/ Carbon Analyzer (Fisons Instruments, Beverly, Mass.)

Media and reagents. Defined aerobic basal medium (DAB) (31) is a phosphate-buffered mineral salts medium amended with minimal concentrations of amino acids, vitamins, and trace elements. $\mathrm{DAB}$ salts medium was used for dilution fluid and is of the same composition as DAB but without vitamin and amino acid amendments. Chloride-free minimal medium was prepared by following the formulation of Wyndham $(\mathrm{A}+\mathrm{N}$ [41]). 3CBA, 99+\%, was purchased from Aldrich Chemical Co., Inc. (Milwaukee, Wis.), and [U- $\left.{ }^{14} \mathrm{C}\right] 3 \mathrm{CBA}(98 \%$; $11.4 \mathrm{mCi} \mathrm{mol}^{-1}$ ) was obtained from California Bionuclear Corp. (Los Angeles, Calif.). 2,4-D and $\left[\mathrm{U}-{ }^{14} \mathrm{C}\right] 2,4-\mathrm{D}\left(10 \mathrm{mCi} \mathrm{mol}^{-1}\right)$ were obtained from Sigma Chemical Co. Medium for the assay of $\left[{ }^{14} \mathrm{C}\right] 2,4-\mathrm{D}$ uptake was composed of $1.7 \%$ agar, DAB, 50 or $200 \mathrm{mg}$ of 2,4-D liter $^{-1}$, and $0.5 \mu \mathrm{Ci}$ of side chain or $\left[\mathrm{U}-{ }^{14} \mathrm{C}\right] 2,4-\mathrm{D}$. The procedure for detecting colonies that take up $\left[{ }^{14} \mathrm{C}\right] 2,4-\mathrm{D}$ is described in Matheson et al. (27). R2A agar (Becton Dickinson Microbiology Systems, Cockeysville, Md.) was used for isolation procedures since we have found that the medium yields a higher diversity of colony types from environmental samples than other heterotrophic media.

Enrichment procedures. Enrichment procedures were designed to mimic the natural soil environment, to maximize the diversity of isolates obtained by maximizing the number of samples enriched, and to limit the enrichment steps and the substrate concentration. We did not want to impose a high degree of selection, thereby losing less fit populations and enriching for genetic changes in culture. We made use of radioactively labeled substrates, microtiter plates, and filter paper carbon dioxide traps (33). For each sample we used two enrichment steps involving $50 \mathrm{ppm}$ of the substrate, isolation of the enriched community on R2A agar, and retesting of each purified isolate (Fig. 1a). In primary enrichments we used 24 of the 30 samples collected from each transect. After the moisture content of the samples was determined, the equivalent of $1 \mathrm{~g}$ (dry weight) was subsampled and placed separately into the wells of a 24-well tissue culture plate (Falcon 3047; Becton Dickinson and Co., Lincoln Park, N.J.). Sterile distilled water and concentrated aqueous stock solutions of unlabeled and labeled substrate were added to each sample to obtain $50 \mathrm{mg}$ of substrate, $0.05 \mu \mathrm{Ci}$ per well, and a final moisture content of $25 \%$. Approximately $5 \mathrm{ml}$ of sterile distilled water was placed in the voids between adjacent wells to reduce desiccation. Plates were covered with sterile filter paper (GB002; Schleicher and Schuell, Keene, N.H.) premoistened with a saturated solution of $\mathrm{BaOH}$ to serve as a ${ }^{14} \mathrm{CO}_{2}$ trap. Plates were incubated in sealed plastic containers at room temperature for up to 2 months. Filter paper traps were removed weekly or biweekly and exposed to X-ray film (X-Omat AR; Kodak, Rochester, N.Y.) for autoradiography. Soil samples that released labeled $\mathrm{CO}_{2}$ were subsampled directly from the primary enrichment wells for secondary enrichments. Approximately $0.1 \mathrm{~g}$ of soil from each positive soil sample was transferred into $1.0 \mathrm{ml}$ of sterile distilled water and mixed by vortexing for $30 \mathrm{~s}$. A $40-\mu \mathrm{l}$ aliquot of the soil suspension was transferred to $160 \mu \mathrm{l}$ of $\mathrm{DAB}$ amended with $50 \mathrm{mg}$ of substrate liter $^{-1}$ and $0.02 \mu \mathrm{Ci}$ of labeled substrate in a 96-well microtiter plate (Falcon 3077; Becton Dickinson and Co.). Suspensions were serially diluted fivefold into the remaining wells to a terminal dilution of $2.56 \times 10^{-6}$. The plates were covered with the $\mathrm{BaOH}$ saturated blotting paper trap and incubated for up to 4 weeks at room temperature. Blotting paper traps were removed weekly and assayed by autoradiography as described above. When activity was first observed on autoradiographs, the most dilute well in which the substrate was mineralized was used for isolation of bacteria responsible for degradation.

Isolation and confirmation of degradation. From the highest-dilution, positive secondary enrichment well, $20 \mu \mathrm{l}$ was transferred into $180 \mu \mathrm{l}$ of DAB salts medium in 96-well microtiter plates and serial dilutions were performed through $10^{-4}$, using a multichannel pipettor. R2A agar plates were inoculated with $100 \mu \mathrm{l}$ from each of the $10^{-3}$ and $10^{-4}$ dilutions, spread with a sterile glass rod, and incubated for 2 to 5 days at room temperature until colony sizes were large enough for transfer. A single colony representative of each morphology present on the isolation plate was streaked onto R2A, and plates were incubated at room temperature for 2 to 5 days to ensure purity. Single, well-isolated colonies were transferred, in parallel, from purification plates to confirmation medium and phosphate-buffered $20 \%$ glycerol for storage at $-80^{\circ} \mathrm{C}$. Medium for confirmation of degradation was the same as that used for secondary enrichment. Isolates were transferred from R2A plates with sterile wooden applicators into individual wells of a 96-well microtiter plate containing $200 \mu \mathrm{l}$ of DAB, $50 \mathrm{mg}$ of substrate liter $^{-1}$, and $0.02 \mu \mathrm{Ci}$ of substrate per well. ${ }^{14} \mathrm{CO}_{2}$ release was monitored as described above. Uninoculated wells served as negative controls, and a known 3CBA degrader (BR60 [41]) or 2,4-D degrader (JMP134 [7]) was used as a positive control. Isolates giving a positive response, i.e., releasing ${ }^{14} \mathrm{CO}_{2}$ from the radiolabeled substrate in this minimal medium, are referred to as mineralizing strains. Glycerol stocks of these mineralizers were inoculated into $3.0 \mathrm{ml}$ of $\mathrm{A}+\mathrm{N}$ broth containing $50 \mathrm{mg}$ of substrate liter $^{-1}$ as the only carbon source. Disappearance of 3CBA and 2,4-D in broth culture was determined by using a Hewlett-Packard (Palo Alto, Calif.) series 1050 high-performance liquid chromatograph (HPLC) equipped with a LiChrosorb RP-18 $(10 \mu \mathrm{m})$ reverse-phase column (E. Merck, Darmstadt, Germany) and a multiple-wavelength detector simultaneously scanning 218,230 , and $280 \mathrm{~nm}$. The mobile phase was $70 \%$ methanol-30\% $0.1 \%$ aqueous $\mathrm{H}_{3} \mathrm{PO}_{4}$. Chromatograms were recorded and integrated with HewlettPackard ChemStation software running on a Gateway 2000 personal computer (Gateway, North Sioux City, S.D.). Chloride release was quantified as described by Bergmann and Sanik (1), using SpectroquantR reagents (E. Merck), and measured spectrophotometrically at $450 \mathrm{~nm}$ with a Bio-Tek EL312e automated plate reader (Bio-Tek Instruments, Inc., Winooski, Vt.).

Quantification of carbon dioxide released from soil enrichments. $\mathrm{BaOH}$ carbon dioxide traps used to indicate mineralization activity in the primary enrichments were also used to quantify the amount of $\mathrm{CO}_{2}$ that had been released over the course of the enrichment periods. $\mathrm{BaOH}$ traps were calibrated with $\mathrm{NaH}^{14} \mathrm{CO}_{3}$ (Sigma Chemical Co.) as follows: 0-, 0.005-, 0.02-, 0.03-, 0.04-, and $0.05-\mu \mathrm{Ci}$ aliquots of a $\mathrm{NaH}^{14} \mathrm{CO}_{3}$ aqueous stock solution were added in quadruplicate to $1 \mathrm{ml}$ of distilled water in the wells of a 24-well tissue culture plate (Fig. 1a). Four such plates were prepared, each with a $\mathrm{BaOH}$ trap with slightly different moisture content. The plates were covered with a filter paper trap and incubated for 1 week. After incubation, the radioactivity in each well was compared with its initial value to determine the loss of $\mathrm{NaH}^{14} \mathrm{CO}_{3}$ from the wells Water $(100 \mu \mathrm{l})$ from the wells was added to $10 \mathrm{ml}$ of Safety-Solve (Research Products International Corp., Mt. Prospect, Ill.) and counted in a Beckman scintillation counter for 1 min. Radioactivity captured as $\mathrm{Ba}^{14} \mathrm{CO}_{3}$ above each well on the $\mathrm{BaOH}$ trap was quantified by an AMBIS Radioanalytic Imaging System (AMBIS, Inc., San Diego, Calif.) equipped with a 3.2- by 3.2-mm resolution screen. Both sides of each filter were scanned for $60 \mathrm{~min}$, and the counts per minute for each well were summed from both sides. These were plotted against the amount of radioactivity lost from the wells. After 1 week of equilibration with the alkaline filter traps, radioactivity in the test wells of the calibration microtiter test plates had dropped to control levels, indicating that all of the bicarbonate had disassociated to carbon dioxide and vaporized. The mean counts per minute of both sides of the filter were summed and plotted against the radioactivity added to that well. The regression of (cpm detected on filter) = 24,900 ( $\mu$ Ci released from well) +24 , with an $r^{2}$ value of 0.9996 (Fig. 1b), was used to convert the radioactivity trapped on each of our enrichment plate filters to microcuries and then to percent $\mathrm{CO}_{2}$ released from the labeled substrates.

\section{RESULTS}

Soil characteristics. The characteristics of the soils that we enriched are shown in Table 1. The soils varied between sites with respect to carbon, nitrogen, soil texture, and moisture content at the time of sampling. All of the soils fell within the acidic to slightly acidic range with the exception of soils from Merredin, Australia, which were highly alkaline.

Soil mineralization activity. 3CBA was mineralized by $96 \%$ of the individual soil samples, while $2,4-\mathrm{D}$ was mineralized by 
TABLE 1. Locations and soil characteristics of sampling sites

\begin{tabular}{|c|c|c|c|c|c|c|c|c|}
\hline $\begin{array}{l}\text { Climate, soil type, } \\
\text { and region }\end{array}$ & $\begin{array}{l}\text { Site } \\
\text { code }\end{array}$ & $\begin{array}{l}\text { Name and geographic } \\
\text { coordinates }^{a}\end{array}$ & Dominant vegetation & $\mathrm{pH}$ & $\begin{array}{c}\% \\
\mathrm{H}_{2} \mathrm{O}\end{array}$ & $\% \mathrm{C}$ & $\% \mathrm{~N}$ & $\begin{array}{c}\text { Texture } \\
\text { (sand/silt/ } \\
\text { clay, \%) }\end{array}$ \\
\hline \multicolumn{9}{|l|}{$\begin{array}{l}\text { Mediterranean, chromic } \\
\text { luvisols }\end{array}$} \\
\hline \multirow[t]{5}{*}{ Southwestern Australia } & $\mathrm{BN}$ & $\begin{array}{l}\text { Bridgetown; } 34^{\circ} 0^{\prime} \mathrm{S} \\
\quad 116^{\circ} 15^{\prime} \mathrm{E}\end{array}$ & Eucalyptus forest & 6.6 & 17.7 & 3.87 & 0.15 & $62: 28: 10$ \\
\hline & GE & $\begin{array}{l}\text { Geraldton; } 28^{\circ} 24^{\prime} \mathrm{S} \\
\quad 114^{\circ} 51^{\prime} \mathrm{E}\end{array}$ & Acacia, , shrublands & 7.2 & 3.1 & 0.80 & 0.08 & $50: 18: 32$ \\
\hline & JD & $\begin{array}{l}\text { Jarrahdale; } 32^{\circ} 23^{\prime} \mathrm{S} \\
\quad 116^{\circ} 07^{\prime} \mathrm{E}\end{array}$ & Dense Eucalyptus forest & 6.7 & 15.2 & 3.01 & 0.11 & $81: 14: 5$ \\
\hline & $\mathrm{KE}$ & $\begin{array}{l}\text { Kelleberrin; } 31^{\circ} 24^{\prime} \mathrm{S} \\
\quad 117^{\circ} 46^{\prime} \mathrm{E}\end{array}$ & Acacia, shrublands & 7.9 & 5.9 & 1.79 & 0.08 & $75: 14: 11$ \\
\hline & $\mathrm{ME}^{b}$ & $\begin{array}{l}\text { Merredin; } 31^{\circ} 23^{\prime} \mathrm{S} \\
\quad 118^{\circ} 41^{\prime} \mathrm{E}\end{array}$ & Eucalyptus, Acacia woodland & 9.1 & 9.4 & 0.60 & 0.04 & $55: 14: 31$ \\
\hline \multirow[t]{5}{*}{ South Africa } & $\mathrm{HH}$ & $\begin{array}{l}\text { Helshoogte; } 33^{\circ} 56^{\prime} \mathrm{S} \\
18^{\circ} 54^{\prime} \mathrm{E}\end{array}$ & Eucalyptus over renosterveld & 5.5 & 9.5 & 3.93 & 0.15 & $52: 30: 18$ \\
\hline & $\mathrm{MB}$ & $\begin{array}{l}\text { Mooreesburg; } 33^{\circ} 4^{\prime} \mathrm{S} \\
18^{\circ} 40^{\prime} \mathrm{E}\end{array}$ & Renosterveld & 6.2 & 4.7 & 0.37 & 0.03 & $72: 22: 6$ \\
\hline & MR & $\begin{array}{l}\text { Mamreweg; } 33^{\circ} 38^{\prime} \mathrm{S} \\
18^{\circ} 28^{\prime} \mathrm{E}\end{array}$ & Renosterveld & 5.8 & 8.5 & 0.57 & 0.05 & $82: 15: 3$ \\
\hline & WG & $\begin{array}{l}\text { Welgevallen; } 33^{\circ} 57^{\prime} \mathrm{S} \\
18^{\circ} 52^{\prime} \mathrm{E}\end{array}$ & Renosterveld/Fynbos & 6.0 & 11.5 & 0.99 & 0.07 & $58: 34: 8$ \\
\hline & $\mathrm{PM}$ & $\begin{array}{l}\text { Paarl Mountain; } \\
33^{\circ} 44^{\prime} \mathrm{S}, 18^{\circ} 56^{\prime} \mathrm{E}\end{array}$ & Fynbos & 6.1 & 14.1 & 1.80 & 0.08 & $63: 22: 6$ \\
\hline \multirow[t]{5}{*}{ California } & $\mathrm{CH}$ & $\begin{array}{l}\text { Chabot; } 37^{\circ} 45^{\prime} \mathrm{N}, \\
122^{\circ} 10^{\prime} \mathrm{W}\end{array}$ & Eucalyptus sp. & 6.2 & 13.4 & 1.78 & 0.11 & $60: 31: 9$ \\
\hline & $\mathrm{CL}$ & $\begin{array}{l}\text { Cloverdale; } 40^{\circ} 29^{\prime} \mathrm{N}, \\
122^{\circ} 29^{\prime} \mathrm{W}\end{array}$ & $\begin{array}{l}\text { Quercus lobata, Q. agrifolia, } \\
\text { Arctostaphylos manzanita }\end{array}$ & 5.8 & 14.2 & 0.97 & 0.05 & $45: 39: 16$ \\
\hline & $\mathrm{HG}$ & $\begin{array}{l}\text { Hillgate; } 40^{\circ} 10^{\prime} \mathrm{N} \\
122^{\circ} 30^{\prime} \mathrm{W}\end{array}$ & $\begin{array}{l}\text { Quercus douglasii, } Q \text {. agrifolia, } \\
\text { grasses }\end{array}$ & 6.4 & 17.2 & 1.11 & 0.10 & $30: 45: 35$ \\
\hline & MU & $\begin{array}{l}\text { Murrieta; } 33^{\circ} 25^{\prime} \mathrm{N}, \\
119^{\circ} 41^{\prime} \mathrm{W}\end{array}$ & $\begin{array}{l}\text { Quercus engelmannii, } Q . \text { agrifolia, } \\
\text { grasses, chaparral }\end{array}$ & 6.1 & 13.8 & 0.61 & 0.05 & $55: 39: 6$ \\
\hline & $\mathrm{VH}$ & $\begin{array}{l}\text { Venice Hills; } 36^{\circ} 20^{\prime} \mathrm{N} \\
119^{\circ} 41^{\prime} \mathrm{W}\end{array}$ & Grasses & 6.4 & 11.6 & 0.85 & 0.08 & $42: 41: 17$ \\
\hline \multirow[t]{5}{*}{ Central Chile } & $\mathrm{RC}$ & $\begin{array}{l}\text { Rio Clarillo; } 33^{\circ} 51^{\prime} \mathrm{S} \\
70^{\circ} 29^{\prime} \mathrm{W}\end{array}$ & Acacia, Cryptocaria, Lithraea & 6.3 & 10.2 & 0.73 & 0.05 & $84: 13: 3$ \\
\hline & LC & $\begin{array}{l}\text { La Campana; } 32^{\circ} 57^{\prime} \mathrm{S} \\
\quad 71^{\circ} 05^{\prime} \mathrm{W}\end{array}$ & $\begin{array}{l}\text { Cryptocaria, Acacia, Lithraea, } \\
\text { Chusquea }\end{array}$ & 6.3 & 26 & 3.47 & 0.21 & $40: 52: 8$ \\
\hline & LP & $\begin{array}{l}\text { Lago Penuelas; } \\
\quad 33^{\circ} 20^{\prime} \mathrm{S}, 71^{\circ} 30^{\prime} \mathrm{W}\end{array}$ & Acacia, Pinus & 6.1 & 11.4 & 0.97 & 0.09 & $67: 21: 12$ \\
\hline & FJ & $\begin{array}{l}\text { Fray Jorge; } 30^{\circ} 38^{\prime} \mathrm{S} \\
\quad 71^{\circ} 35^{\prime} \mathrm{W}\end{array}$ & $\begin{array}{l}\text { Kageneckia, Myrceugenia, } \\
\text { Margyricarpu, Drimys }\end{array}$ & 6.8 & 3.6 & 0.89 & 0.07 & $77: 185$ \\
\hline & EG & Pinque & Eucalyptus & & 7.7 & $\mathrm{ND}^{c}$ & ND & \\
\hline \multicolumn{9}{|l|}{ Boreal forest, albic luvisols } \\
\hline \multirow[t]{5}{*}{ Saskatchewan } & BT & $\begin{array}{l}\text { Bittern; } 53^{\circ} 55^{\prime} \mathrm{N} \\
105^{\circ} 27^{\prime} \mathrm{W}\end{array}$ & $\begin{array}{l}\text { Picea glauca, Populus tacamahaca, } \\
\text { Betula papyrifera }\end{array}$ & 5.7 & 14.3 & 0.86 & 0.05 & $59: 37: 7$ \\
\hline & $\mathrm{NP}$ & $\begin{array}{l}\text { Napatak; } 54^{\circ} 52^{\prime} \mathrm{N} \\
\quad 105^{\circ} 24^{\prime} \mathrm{W}\end{array}$ & Pinus banksiana, Picea glauca & 5.8 & 21.6 & 1.07 & 0.05 & $58: 31: 11$ \\
\hline & PC & $\begin{array}{l}\text { Porcupine; } 52^{\circ} 39^{\prime} \mathrm{N}, \\
102^{\circ} 23^{\prime} \mathrm{W}\end{array}$ & Populus tacamahaca & 6.4 & 29.0 & 4.83 & 0.33 & $58: 34: 8$ \\
\hline & WV & $\begin{array}{l}\text { Waitville; } 53^{\circ} 41^{\prime} \mathrm{N}, \\
105^{\circ} 22^{\prime} \mathrm{W}\end{array}$ & $\begin{array}{l}\text { Picea glauca, Pinus banksiana, } \\
\text { Betula papyrifera }\end{array}$ & 6.1 & 16.9 & 1.31 & 0.05 & $47: 50: 3$ \\
\hline & WK & $\begin{array}{l}\text { Waskesieu; } 54^{\circ} 0^{\prime} \mathrm{N} \\
106^{\circ} 35^{\prime} \mathrm{W}\end{array}$ & $\begin{array}{l}\text { Pinus banksiana, Picea glauca, } \\
\text { Betula papyrifera }\end{array}$ & 6.1 & 12.6 & 0.82 & 0.05 & $14: 74: 12$ \\
\hline \multirow[t]{4}{*}{ Russia } & RI & $38^{\circ} 0^{\prime} \mathrm{E}, 60^{\circ} 0^{\prime} \mathrm{N}$ & Picea abies, Populus alba & 4.9 & 28.7 & 0.8 & 0.04 & $54: 38: 8$ \\
\hline & RII & $38^{\circ} 30^{\prime} \mathrm{E}, 60^{\circ} 30^{\prime} \mathrm{N}$ & Picea abies, Populus alba & 4.8 & 28.8 & 4.85 & 0.13 & $54: 41: 5$ \\
\hline & RIII & $39^{\circ} 0^{\prime} \mathrm{N}, 60^{\circ} 30^{\prime} \mathrm{N}$ & $\begin{array}{l}\text { Pinus sylvestris, Picea abies, } \\
\quad \text { Populus alba }\end{array}$ & 4.6 & 32.5 & 0.35 & 0.03 & $79: 17: 4$ \\
\hline & RIV & $39^{\circ} 0^{\prime} \mathrm{E}, 61^{\circ} 0^{\prime} \mathrm{N}$ & $\begin{array}{l}\text { Pinus sylvestris, Picea abies, } \\
\quad \text { Populus alba }\end{array}$ & 4.8 & 27.3 & 1.83 & 0.07 & $78: 18: 4$ \\
\hline
\end{tabular}

${ }^{a}$ Determined by a geographic positioning system.

${ }^{b}$ Although the area was mapped as a chromic luvisol, the soil at this site contained lime deposits.

${ }^{c} \mathrm{ND}$, not determined. 
(b)

(a)
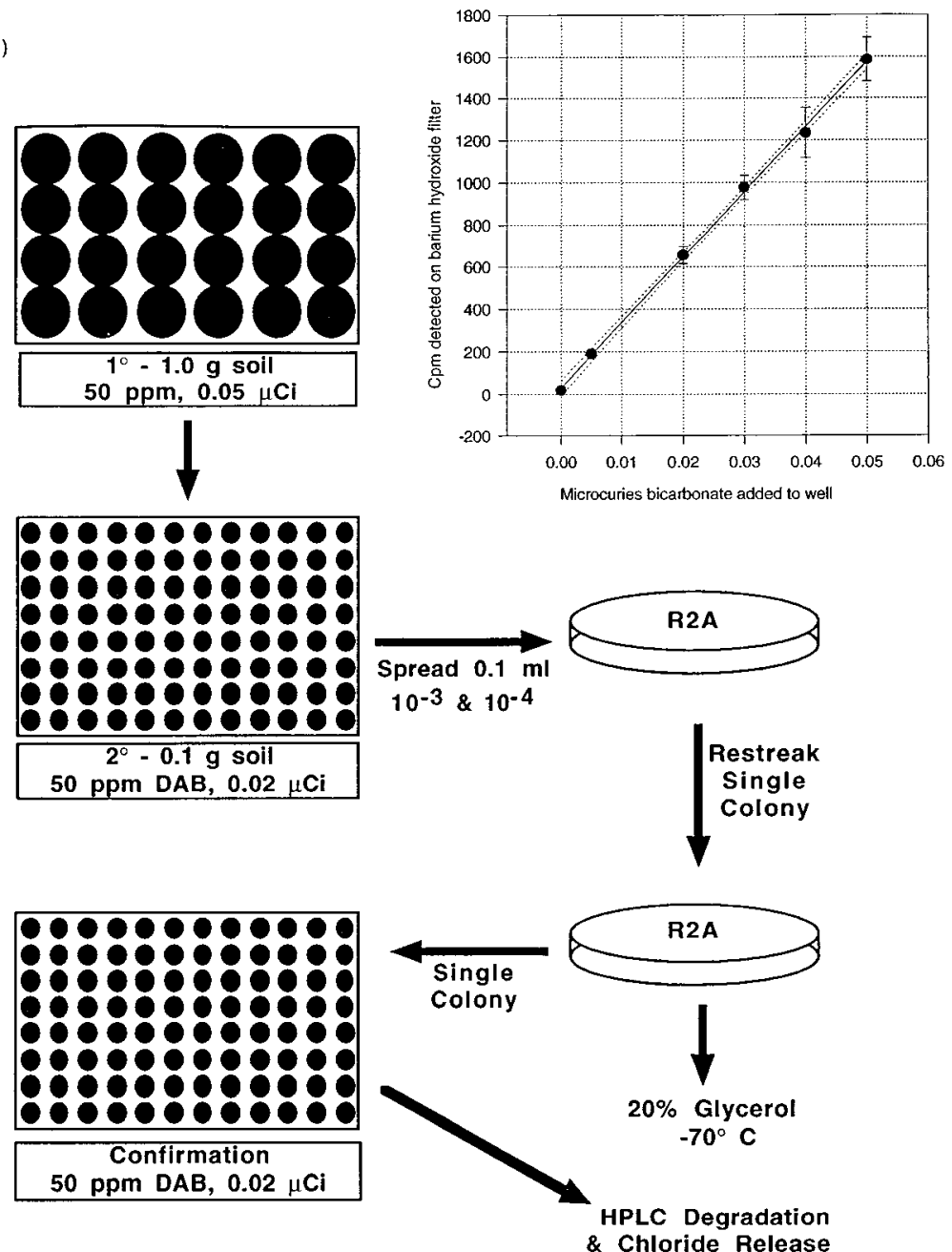

FIG. 1. (a) Illustration of enrichment protocol used. (b) Calibration of barium hydroxide carbon dioxide traps: relationship between ${ }^{14} \mathrm{CO}_{2}$ trapped on filter and ${ }^{14} \mathrm{CO}_{2}$ released.

only $59 \%$ (Table 2). Thus, 3CBA degradation was observed at all sites and virtually all samples along each transect, whereas 2,4-D mineralization was observed at all sites but had a patchy distribution at the transect level: some samples from each transect exhibited mineralization while others did not. The Saskatchewan samples were an exception to this; all of these samples exhibited 2,4-D mineralization. Our success in obtaining active secondary enrichment cultures also varied with the substrate. 3CBA mineralization activity was more easily transferred from the primary to the secondary cultures than was 2,4-D mineralization (but again, Saskatchewan samples were the exception).

In four of the six regions, the lag phase prior to degradation of the two chemicals was different. In these areas, CBA mineralization was well under way in the first week, while 2,4-D mineralization did not start until the second week (Fig. 2). This pattern is typified by the Australian samples, in which all of the sites mineralized more 3CBA than 2,4-D (Fig. 3a). In contrast, in California and Chile, the lag period was the same, and significant mineralization of both 3CBA and 2,4-D was not seen until the second week (Fig. 3b).

In some regions, the overall rates of mineralization also differed between the chemicals. In Western Australia, California, and most of the South African sites, 2,4-D mineralization rates were lower than those of 3CBA. This was also true for two of the Saskatchewan and Chilean sites (Fig. 2).

Mineralization rates varied between samples in the same transect as well as between sites (Fig. 2). We examined physical and chemical data to explain these variances. We performed carbon and nitrogen analyses on all 24 transect samples for four sites, but we could not detect significant correlations between mineralization rates and these nutrient data or between mineralization rates and the field moisture contents. We also could not detect any significant correlations between site average mineralization rates and average field moisture content, carbon or nitrogen content, carbon/nitrogen ratios, $\mathrm{pH}$, or the textural data.

Degrader isolation success. We isolated 610 3CBA-mineralizing strains from the isolates cultivated from actively degrading secondary enrichments (Table 2). Across the sites, these strains account for 30 to $55 \%$ of the colony types that arose after initial plating on R2A agar. We compared this percentage to that obtained when soils were enriched on alternate substrates. When a subset of the soils (four from each region) was 
TABLE 2. Number of soil enrichments and isolates that mineralized 3CBA and 2,4-D

\begin{tabular}{|c|c|c|c|c|c|c|}
\hline Region & $\begin{array}{c}\text { No. of soil } \\
\text { samples }\end{array}$ & Substrate & $\begin{array}{l}\text { Positive primary } \\
\text { enrichments }(\%)\end{array}$ & $\begin{array}{l}\text { Positive secondary } \\
\text { enrichments }(\%)\end{array}$ & $\begin{array}{l}\text { No. of isolates } \\
\text { releasing } \mathrm{CO}_{2}\end{array}$ & $\begin{array}{c}\text { No. of isolates } \\
\text { degrading }>80 \%\end{array}$ \\
\hline California & 116 & $\begin{array}{l}3 \mathrm{CBA} \\
2,4-\mathrm{D}\end{array}$ & $\begin{array}{l}99 \\
50\end{array}$ & $\begin{array}{l}92 \\
41\end{array}$ & $\begin{array}{r}92 \\
0\end{array}$ & 15 \\
\hline Chile & 96 & $\begin{array}{l}3 \mathrm{CBA} \\
2,4-\mathrm{D}\end{array}$ & $\begin{array}{l}86 \\
54\end{array}$ & $\begin{array}{l}69 \\
35\end{array}$ & $\begin{array}{r}68 \\
2\end{array}$ & $\begin{array}{c}13 \\
\mathrm{ND}^{a}\end{array}$ \\
\hline South Africa & 120 & $\begin{array}{l}3 \mathrm{CBA} \\
2,4-\mathrm{D}\end{array}$ & $\begin{array}{l}98 \\
63\end{array}$ & $\begin{array}{l}98 \\
18\end{array}$ & $\begin{array}{r}149 \\
2\end{array}$ & $\begin{array}{r}56 \\
\text { ND }\end{array}$ \\
\hline Australia & 120 & $\begin{array}{l}3 \mathrm{CBA} \\
2,4-\mathrm{D}\end{array}$ & $\begin{array}{l}90 \\
53\end{array}$ & $\begin{array}{r}50 \\
3\end{array}$ & $\begin{array}{r}101 \\
0\end{array}$ & 7 \\
\hline Saskatchewan & 120 & $\begin{array}{l}3 \mathrm{CBA} \\
2,4-\mathrm{D}\end{array}$ & $\begin{array}{l}100 \\
100\end{array}$ & $\begin{array}{r}91 \\
100\end{array}$ & $\begin{array}{r}119 \\
0\end{array}$ & 30 \\
\hline Russia & 96 & $\begin{array}{l}3 \mathrm{CBA} \\
2,4-\mathrm{D}\end{array}$ & $\begin{array}{r}100 \\
57\end{array}$ & $\begin{array}{l}84 \\
26\end{array}$ & $\begin{array}{r}81 \\
1\end{array}$ & $\begin{array}{r}23 \\
\mathrm{ND}\end{array}$ \\
\hline Total & 668 & $\begin{array}{l}3 \mathrm{CBA} \\
2,4-\mathrm{D}\end{array}$ & $\begin{array}{l}96 \\
59\end{array}$ & $\begin{array}{l}81 \\
38\end{array}$ & $\begin{array}{r}610 \\
5\end{array}$ & $\begin{array}{l}144 \\
\text { ND }\end{array}$ \\
\hline
\end{tabular}

${ }^{a} \mathrm{ND}$, not determined.

enriched using the same procedures on benzoate (a nonchlorinated analog) or a mixture of succinate and pyruvate (intermediates in aromatic degradation), $30 \%$ or less of the colony types were 3CBA mineralizers (Fig. 4). Colony types arising on R2A after all of the soils were enriched on 2,4-D were also tested for 3CBA mineralization. For all soils except those from Saskatchewan and South Africa, less than $10 \%$ of these strains were 3CBA mineralizers. In soils from these two regions, enrichment on 2,4-D seemed to select for 3CBA mineralizers, producing secondary enrichment communities with $>50 \%$ of the R2A culturable colony types capable of 3CBA mineralization (Fig. 4).

2,4-D mineralizers proved extremely difficult to isolate. Only five of the colony types tested after 2,4-D enrichment and plating on R2A were capable of releasing carbon dioxide from

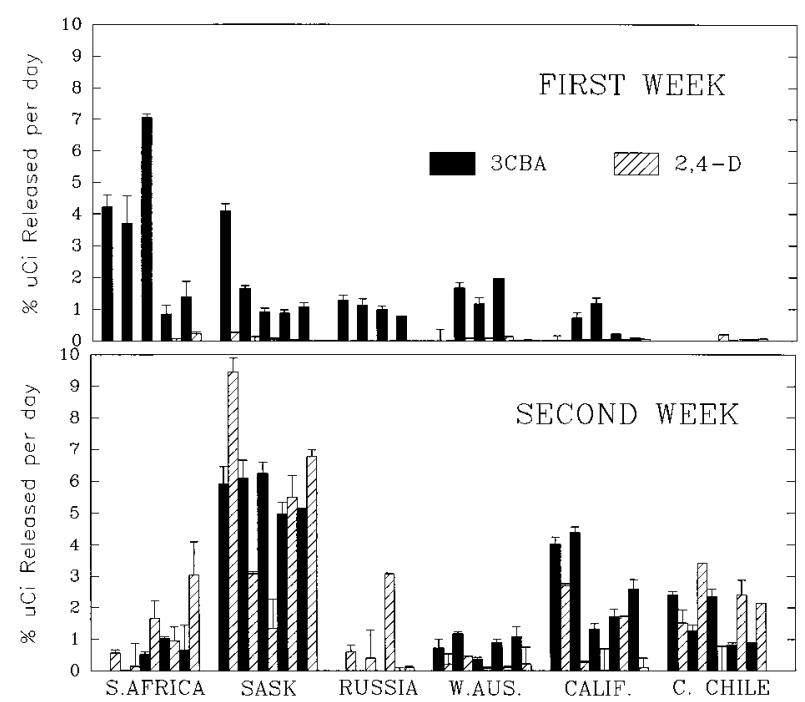

FIG. 2. Rates of mineralization of 3CBA and 2,4-D obtained for each site in the first and second weeks after enrichment. Data for 3CBA degradation in Russian soils in the second week were not obtained.
2,4-D (Table 2). Enrichments were repeated with and without the addition of a mixture of two fungal inhibitors $(100 \mathrm{ppm}$ of cycloheximide and $5 \mathrm{ppm}$ of nystatin) to the soil and liquid media, but 2,4-D mineralization was unaffected by these antifungal compounds. In an attempt to find the bacteria responsible for 2,4-D degradation in our original active secondary enrichment cultures, we subjected the R2A isolates to further tests. Isolates from R2A were grown on nitrocellulose filters overlying 2,4-D solid media labeled with $0.5 \mu \mathrm{Ci}$ of $\left[{ }^{14} \mathrm{C}\right] 2,4-\mathrm{D}$ in order to detect colonies that may be taking up side chain or ring-labeled 2,4-D but not mineralizing it. Only the control organism (Alcaligenes eutrophus JMP134 [7]) gave positive signals after autoradiography of the nitrocellulose filters. We then attempted to isolate the 2,4-D degraders by avoiding the use of $\mathrm{R} 2 \mathrm{~A}$. The enrichment procedures were repeated and mineralizing secondary enrichment cultures were plated on solid media, nearly identical in composition to that of the secondary enrichment cultures. These media had 50 or $200 \mathrm{mg}$ of 2,4-D liter $^{-1}$ in DAB and were made both with and without soil extract. Dilutions of secondary enrichments were plated on nitrocellulose filters over these media and transferred after 7 days to fresh media containing $0.5 \mu \mathrm{Ci}$ of ring-labeled or side chain-labeled 2,4-D. Small colonies grew on the filters, but no colonies showed uptake of the labeled compounds. In another attempt to recover the active 2,4-D degraders, secondary enrichment cultures were plated without dilution on selective media (200 mg of 2,4-D liter ${ }^{-1}$ in DAB with soil extract) and allowed to grow for 3 weeks. All large colonies were transferred with sterile toothpicks, without attempts to purify the colonies, to a nitrocellulose filter on solid medium labeled with $\left[{ }^{14} \mathrm{C}\right] 2,4-\mathrm{D}$ and allowed to grow for an additional 7 days. Again, only the control organism, A. eutrophus JMP134, gave a positive response.

\section{DISCUSSION}

This study revealed three important points. First, the ability to mineralize 3CBA and 2,4-D was a common property of the microbial communities of undisturbed, pristine soils. Second, the mineralization of the two chemicals by the soils differed 
a South Western Australian Soils

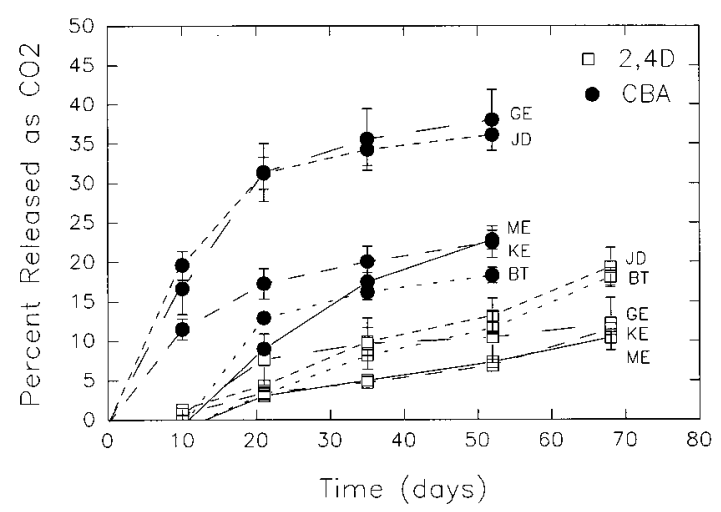

b

$$
\text { Centrol Chilean Soils }
$$

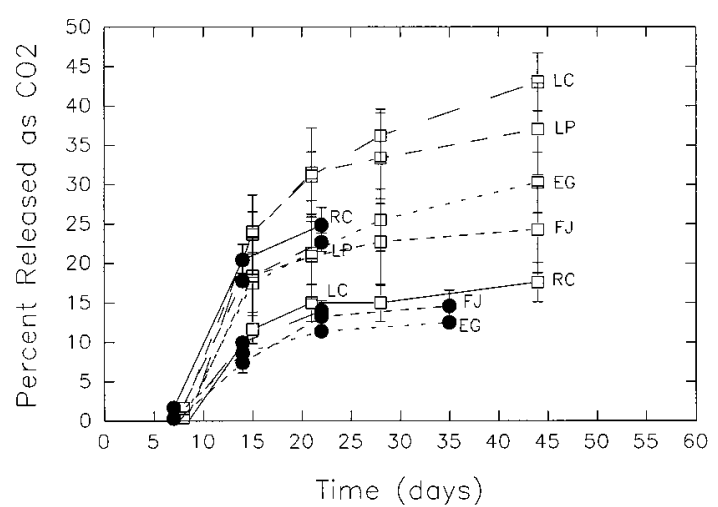

FIG. 3. Average ${ }^{14} \mathrm{CO}_{2}$ released from $\left[{ }^{14} \mathrm{C}\right] 3 \mathrm{CBA}$ and $\left[{ }^{14} \mathrm{C}\right] 2,4-\mathrm{D}$ from each site for (a) southwestern Australia and (b) central Chile. Error bars are standard errors for each transect $(n=24)$. Letters adjacent to each plot indicate the site codes (Table 1)

with respect to lag phase and overall rates in many of the soil samples. Third, the organisms that carried out the mineralization of 3CBA and 2,4-D had different spatial distributions and culturability characteristics.

Previous studies have shown that 2,4-D degraders are relatively easy to isolate from soil and that 3CBA degraders are rare $(3,9,12,20,21)$. There are two possible reasons for the discrepancy between our results and earlier ones. First, there may be significant differences in the community composition of the microflora of forested or woodland soils and the typical agricultural soils that are usually studied. Second, differences in methodologies may account for the results. If researchers have relied on plating procedures to determine the presence or absence of degraders, then the inadequacy of laboratory media to detect these degraders may be responsible. However, if degradation studies indicate that the chemical does not disappear (3), then it is likely that the seed sources (the soils or sludges) are, indeed, carrying different microflora.

The large number of 3CBA degraders isolated from these soils might suggest that selection for chloroaromatic degradation has occurred. The source of such selective compounds is not apparent. All of the sites were from natural ecosystems that had never been cultivated or directly exposed to agricultural or industrial wastes. However, recent reports indicate that vegetation can absorb and concentrate organic pollutants transported by the atmosphere $(32,37)$. In order to support heterotrophic growth and therefore selection, 3CBA and 2,4-D would have to accumulate in soil to levels greater than about $0.1 \mathrm{ppm}$ (24). Both of these chemicals are nonvolatile and fairly hydrophilic, two factors that make it unlikely that global atmospheric transport would result in these kinds of concentrations (32). Localized drift from agricultural areas may account for some exposure to 2,4-D, but the highest activity against both 3CBA and 2,4-D was seen in the Saskatchewan boreal forest soils. These sites were in remote areas adjacent to some logging activities carried out by Weyerhaeuser Canada, which is responsible for the harvest and replanting of Saskatchewan timber forest. Although 2,4-D is often used in forestry management operations, this particular company does not use 2,4-D anywhere in the province. In addition, one sampling site (Waskesiu) was located in the center of Prince Albert National Park, a park established in 1928 that does not permit logging or herbicide spraying.

A second and perhaps more parsimonious explanation for this widespread soil property is that $3 \mathrm{CBA}$ and, to a lesser extent, 2,4-D are at least analogs of naturally occurring compounds found in the biomes that we looked at (Mediterranean areas and boreal forests). The putative analogs may be chlorinated or nonchlorinated. Naturally produced organochlorine compounds are being discovered with increasing frequency, although they are primarily of marine origin (14). Most significantly, a recent study reports the production of up to $75 \mathrm{mg}$ of chlorinated anisaldehydes and anisalcohols liter ${ }^{-1}$ by wood decay fungi that are common in natural soil environments (6). However, the normal substrate of these microorganisms could well be nonchlorinated compounds, which they metabolize with catabolic enzymes that have broad substrate ranges.

We did not expect 3CBA and 2,4-D mineralizers to display different distributions, i.e., to have 3CBA mineralization occurring in virtually all of the soil samples but 2,4-D mineralization occurring in just over half of the samples from each transect. The majority of 2,4-D mineralizers that have been studied carry genes that are at least homologous, if not identical, to the $t f d$ genes on plasmid pJP4, and they encode genes that can mediate $3 \mathrm{CBA}$ as well as $2,4-\mathrm{D}$ degradation via ortho cleavage of chlorocatechols. The genes are also globally distributed on conjugative plasmids (10). This study shows that the two capabilities are not congruent in these pristine ecosys-

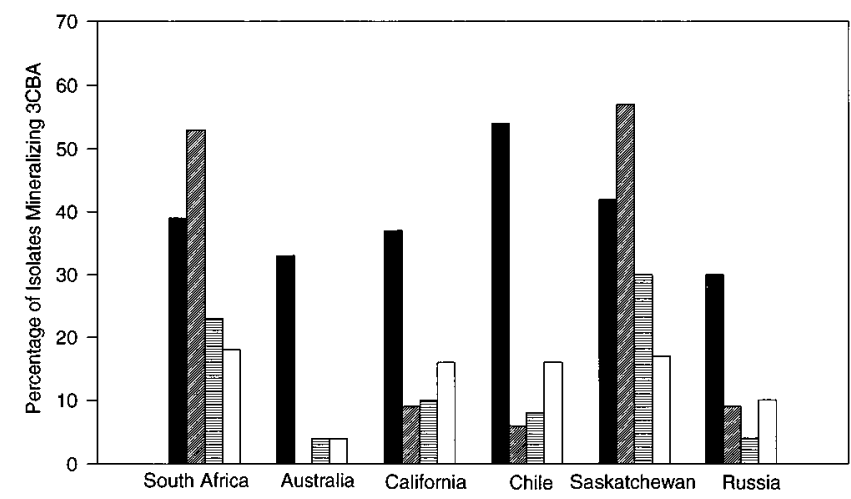

FIG. 4. Percentage of isolates appearing on R2A that could also release ${ }^{14} \mathrm{CO}_{2}$ from $\left[{ }^{14} \mathrm{C}\right] 3 \mathrm{CBA}$ after primary and secondary soil enrichments on the indicated substrates. Percentages from 3CBA and 2,4-D enrichments were calculated from isolates obtained after the enrichment of all soil samples, while percentages from benzoate and succinate-pyruvate enrichments were calculated from isolates obtained after enrichment of four samples from each region (total of 24). Isolates from the Australian 2,4-D enrichments were not examined. $50 \mathrm{ppm}$ of 3CBA; 5 , $50 \mathrm{ppm}$ of 2,4-D; 焉, $50 \mathrm{ppm}$ of benzoate; $\square, 25 \mathrm{ppm}$ of succinate plus $25 \mathrm{ppm}$ of pyruvate. 
tems. Preliminary results (11) indicate that 3CBA degraders do metabolize 3CBA via chlorocatechols, and if this is so, their inability to mineralize 2,4-D may be due to a lack of a $t f d A$-like etherase gene or an inability to metabolize dichlorocatechol. Our data could reflect the more restricted distribution of one of these genes.

When enriching agricultural or urban soils on 2,4-D, culturable degraders related to Burkholderia cepacia, Pseudomonas putida, Arthrobacter sp., or Sphingomonas sp. are easily isolated. However, with the exception of five strains isolated from three different regions, all of our attempts to culture 2,4-D degraders from these soils, using the same methods that successfully yielded 3CBA degraders, met with failure. Others in our group have experienced the same difficulty in isolating 2,4-D degraders from both this collection and nonagricultural Hawaii soils (35). There are several potential explanations. The degraders may require conditions that are not met during isolation; e.g., they are microaerophilic or unable to grow on agar. Alternatively, the degradation may take place via a consortium of organisms (for instance, by one organism with a tfd $A$-like function and a chlorobenzoate degrader). In both the South African and the Saskatchewan soils, 2,4-D enrichment selected for 3CBA degraders in the secondary enrichment cultures. In these cases the $3 \mathrm{CBA}$ degraders may be playing a intermediary role in 2,4-D degradation; hence, at least two organisms would be involved.

The method used in this study made it possible to monitor the mineralization of substrates in numerous soil samples simultaneously under seminatural conditions (i.e., $25 \%$ moisture). It proved to be both reliable and efficient; nearly 700 individual soil samples from six geographic regions were analyzed. This effort would have been unmanageable by traditional respirometry methods. Quantification was simplified with the radioactive AMBIS scanner.

3CBA degraders were easy to isolate, but at the same time, isolates were not obtained from all positive enrichments. R2A was chosen as an isolation medium because it consistently allowed the cultivation of the greatest number and diversity of bacterial isolates from Michigan soils (9a). Even so, we were not able to isolate 3CBA degraders from all of the positive secondary enrichments, so the 610 strains we obtained were not fully representative of those active in soils. In addition, many strains lost the ability to release carbon dioxide after isolation. We analyzed 533 of the original 610 mineralizers for the degradation of 3CBA in 3-ml static liquid cultures. Under these conditions, only 155 released chloride and completely degraded the 3CBA. The remaining 378 transformed the compound to some extent, and we assume these bacteria had inefficient enzymes or were genetically unstable. It is tempting to focus future physiological and genetic experiments on the "well-behaved" 155 bacteria in our collection; however, by examining only some of the degraders, an incomplete picture of the 3CBA-degrading community in natural environments may be produced.

This study has shown that 3CBA and 2,4-D degraders are widespread in areas where one would not expect them to have a selective advantage. Although historically these two compounds are assumed to be degraded via homologous degradative pathways, in the soils we examined these very similar chemicals are apparently metabolized via different microbial populations.

\section{ACKNOWLEDGMENTS}

This research was supported by National Science Foundation grant BIR9120006 and is part of the Joint Research Project on Microbial Evolution with the Research and Development Corporation of Japan
(JRDC). A grant from the U.S. Air Force to A.N.R. provided some supplies.

We are indebted to the following people for their help in the soil sampling: Paula Webster and Ricardo Serrano (Chile); Jane Krafchuk (Saskatchewan); James Fullard, Michael Loos, and Jan Lambrecht (South Africa); Ian Dadour (Australia); Gary Bell and Larry Sonen (California); and Tamara Tsoi, V. Grischenkov, and Olga Maltseva (Russia). We thank R. Sroufe for technical support; D. Harris for performing the carbon and nitrogen analyses and D. Mokma for the textural analysis; and L. J. Forney, W. H. Holben, and R. Sanford for helpful technical direction and useful discussions at the outset of this project.

\section{REFERENCES}

1. Bergmann, J. G., and J. Sanik. 1957. Determination of trace amounts of chlorine in naphtha. Anal. Chem. 29:241-243.

2. Bhat, M. A., M. Tsuda, K. Horike, M. Nozaki, C. S. Vaidyanathan, and T. Nakazawa. 1994. Identification and characterization of a new plasmid carrying genes for degradation of 2,4-dichlorophenoxyacetate from Pseudomonas cepacia CSV90. Appl. Environ. Microbiol. 60:307-312.

3. Brunsbach, F. R., and W. Reineke. 1993. Degradation of chlorobenzoates in soil slurry by special organisms. Appl. Microbiol. Biotechnol. 39:117-122.

4. Chaudry, G. R., and G. H. Huang. 1988. Isolation and characterization of a new plasmid from a Flavobacterium sp. which carries the genes for degradation of 2,4-dichlorophenoxyacetate. J. Bacteriol. 170:3897-3902.

5. Day, P. R. 1965. Particle fractionation and particle size analysis, p. 545-567. In C. A. Black (ed.), Methods of soils analysis, vol. 1. American Society of Agronomy, Madison, Wis.

6. de Jong, E., J. A. Field, H.-E. Spinnler, J. B. P. A. Wignberg, and J. A. M. de Bont. 1994. Significant biogenesis of chlorinated aromatics by fungi in natural environments. Appl. Environ. Microbiol. 60:264-270.

7. Don, R. H., and J. M. Pemberton. 1981. Properties of six pesticide degradation plasmids isolated from Alcaligenes paradoxus and Alcaligenes eutrophus. J. Bacteriol. 145:681-686.

8. Dorn, E., M. Hellwig, W. Reineke, and H.-J. Knackmuss. 1974. Isolation and characterization of a 3-chlorobenzoate degrading pseudomonad. Arch. Microbiol. 99:61-70.

9. Focht, D. D., and D. Shelton. 1987. Growth kinetics of Pseudomonas alcaligenes $\mathrm{C}-0$ relative to inoculation and 3-chlorobenzoate metabolism in soil. Appl. Environ. Microbiol. 53:1846-1849.

9a.Fulthorpe, R. R. Unpublished data.

10. Fulthorpe, R. R., C. McGowan, O. V. Maltseva, W. E. Holben, and J. M. Tiedje. 1995. 2,4-Dichlorphenoxyacetic acid-degrading bacteria contain mosaics of catabolic genes. Appl. Environ. Microbiol. 61:3274-3281.

11. Fulthorpe, R. R., A. N. Rhodes, and J. M. Tiedje. 1994. Abundant and genetically diverse 3-chlorobenzoate degraders with novel catabolic genes found in pristine soils, abstr. Q-152. In Abstracts of the 94th General Meeting of the American Society for Microbiology 1994. American Society for Microbiology, Washington, D.C.

12. Fulthorpe, R. R., and R. C. Wyndham. 1989. Survival and activity of a 3-chlorobenzoate-catabolic genotype in a natural system. Appl. Environ. Microbiol. 55:1584-1590.

13. Furukawa, K., N. Tomizuka, and A. Kamibayashi. 1979. Effect of chlorine substitution on the bacterial metabolism of various polychlorinated biphenyls. Appl. Environ. Microbiol. 38:301-310.

14. Gribble, G. W. 1992. Naturally occurring organohalogen compounds-a survey. J. Nat. Prod. (Lloydia) 55:1353-1395.

15. Grishchenkov, V. G., I. E. Fedevichkina, B. P. Baskunov, L. A. Anisimova, A. M. Boronin, and L. A. Gololeva. 1984. Degradation of 3-chlorobenzoic acid by a Pseudomonas putida strain. Mikrobiologiya 52:771-776.

16. Haggblom, M. M. 1992. Microbial breakdown of halogenated aromatic pesticides and related compounds. FEMS Microbiol. Rev. 103:29-72.

17. Haller, H. D., and R. K. Finn. 1979. Biodegradation of 3-chlorobenzoate and formation of black color in the presence and absence of benzoate. Eur. J. Appl. Microbiol. 8:191-205.

18. Harkness, M. R., J. B. McDermott, D. A. Abramawicz, J. J. Salvo, W. P. Flanagan, M. L. Stephens, F. J. Mondello, R. J. May, J. H. Lobos, K. M. Carroll, M. J. Brennan, A. A. Bracco, K. M. Fish, G. L. Warner, P. R. Wilson, D. K. Dietrich, D. T. Lin, C. B. Morgan, and W. L. Gately. 1993. In situ stimulation of aerobic PCB biodegradation in Hudson River sediments. Science 259:503-507.

19. Hartmann, J., W. Reineke, and H.-J. Knackmuss. 1979. Metabolism of 3-chloro-, 4-chloro-, and 3,5-dichlorobenzoate by a pseudomonad. Appl. Environ. Microbiol. 37:421-428.

20. Hernandez, B. S., J. J. Arensdorf, and D. D. Focht. 1995. Catabolic characteristics of biphenyl-utilizing isolates which cometabolize PCBs. Biodegradation 6:75-82.

21. Hickey, W. J., and D. D. Focht. 1990. Degradation of mono-, di-, and trihalogenated benzoic acids by Pseudomonas aeruginosa JB2. Appl. Environ. Microbiol. 56:3842-3850.

22. Hickey, W. J., D. B. Searles, and D. D. Focht. 1993. Enhanced mineralization 
of polychlorinated biphenyls in soil inoculated with chlorobenzoate-degrading bacteria. Appl. Environ. Microbiol. 59:1194-1200.

23. Johnston, H. W., G. G. Briggs, and M. Alexander. 1972. Metabolism of 3-chlorobenzoic acid by a pseudomonad. Soil Biol. Biochem. 4:187-190.

24. Ka, J. O., W. E. Holben, and J. M. Tiedje. 1994. Genetic and phenotypic diversity of 2,4-dichlorophenoxyacetic acid (2,4-D)-degrading bacteria isolated from 2,4-D-treated field soils. Appl. Environ. Microbiol. 60:1106-1115.

25. Krumme, M. L. 1993. Development of aquifer microcosms and in situ methods to test the fate and function of pollutant-degrading microorganisms. Ph.D. dissertation. Technische Universität Carolo-Wilhelmina, Braunschweig, Germany.

26. Mae, A. A., R. O. Marits, N. R. Ausmees, V. M. Koiv, and A. L. Heinaru. 1993. Characterization of a new 2,4-dichlorophenoxyacetic acid degrading plasmid pEST4011: physical map and localization of catabolic genes. J. Gen. Microbiol. 139:3165-3170.

27. Matheson, V. G., L. J. Forney, Y. Suwa, C. H. Nakatsu, A. J. Sexstone, and W. E. Holben. Evidence for acquisition in nature of chromosomal 2,4-Detherase gene by different species of Burkholderia. Appl. Environ. Microbiol., in press.

28. Nakatsu, C. H., and R. C. Wyndham. 1993. Cloning and expression of the transposable chlorobenzoate-3,4-dioxygenase genes of Alcaligenes sp. strain BR60. Appl. Environ. Microbiol. 59:3625-3633.

29. Perkins, E. J., M. P. Gordon, O. Caceres, and P. F. Lurquin. 1990. Organization and sequence analysis of the 2,4-dichlorophenol hydroxylase and dichlorocatechol oxidative operons of plasmid pJP4. J. Bacteriol. 172:23512359.

30. Pertsova, R. N., F. Kunc, and L. A. Golovleva. 1984. Degradation of 3-chlorobenzoate in soil by pseudomonads carrying biodegradative plasmids. Folia Microbiol. 29:242-247.

31. Rhodes, A. N. 1994. Distribution and catabolic diversity of 3-chlorobenzoate acid degrading bacteria isolated from geographically separated pristine soils. $\mathrm{Ph} . \mathrm{D}$. thesis. Michigan State University, East Lansing.

32. Simonich, S. L., and R. A. Hites. 1995. Global distribution of persistent organochlorine compounds. Science 269:1851-1854.

33. Tabor, H., C. W. Tabor, and E. W. Hafner. 1975. Convenient method for detecting ${ }^{14} \mathrm{CO}_{2}$ in multiple samples: application to rapid screening for mutants. J. Bacteriol. 128:485-486.

34. Taeger, K., H. J. Knackmuss, and E. Schmidt. 1988. Biodegradability of mixtures of chloro- and methylsubstituted aromatics: simultaneous degradation of 3-chlorobenzoate and 3-methylbenzoate. Appl. Microbiol. Biotechnol. 28:603-608.

35. Takami, H., Y. Kamagata, R. Fulthorpe, L. J. Forney, and J. M. Tiedje. 1994. Microbial communities degrading 2,4-dichlorophenoxyacetate in pristine soils, abstr. N-45. In Abstracts of the 94th General Meeting of the American Society for Microbiology 1994. American Society for Microbiology, Washington, D.C.

36. Theim, S. M., M. L. Krumme, R. L. Smith, and J. M. Tiedje. 1994. Use of molecular techniques to evaluate the survival of a microorganism injected into an aquifer. Appl. Environ. Microbiol. 60:1059-1067.

37. Thompson, R. S., and R. G. Treble. 1995. Use of pine needles as an indicator of atmospheric contamination by pentachlorophenol. Chemosphere 31: 4387-4392.

38. Tonso, N. L., V. G. Matheson, and W. E. Holben. 1995. Polyphasic characterization of a suite of bacterial isolates capable of degrading 2,4-D. Microb. Ecol. 30:3-24.

39. van der Meer, J. R., W. M. De Vos, S. Harayama, and A. J. B. Zehnder. 1992 Molecular mechanisms of genetic adaptation to xenobiotic compounds. Microbiol. Rev. 56:677-704.

40. Weisshaar, M.-P., F. C. H. Franklin, and W. Reineke, 1987. Molecular cloning and expression of the 3-chlorobenzoate-degrading genes from Pseudomonas sp. strain B13. J. Bacteriol. 169:394-402.

41. Wyndham, R. C. 1986 . Evolved aniline catabolism in Acinetobacter calcoaceticus during continuous culture of river water. Appl. Environ. Microbiol. 51 781-789.

42. Wyndham, R. C., and N. A. Strauss. 1988. Chlorobenzoate catabolism and interactions between Alcaligenes and Pseudomonas species from Bloody Run Creek. Arch. Microbiol. 150:230-236.

43. Zaitsev, G. M., and B. P. Baskunov. 1985. Utilization of 3-chlorobenzoic acid by Acinetobacter. Mikrobiologiya 54:203-208. 